\title{
Research on the Development of Housing Industrialization under the New Urbanization
}

\author{
Cheng Liu ${ }^{{ }^{*}}$, Li Wang ${ }^{2}$ \\ ${ }^{1}$ Department of Management, Xi'an University of Finance and Economics, Xi'an 710061, China \\ ${ }^{2}$ Department of Xingzhi University, Xi'an University of Finance and Economics, Xi'an 710061, China
}

Funding: On March 15, 2021, supported by the 2019 soft science project of Shaanxi Provincial Science and Technology Department, research on the development path and countermeasures of Shaanxi urban and rural housing industrialization (Project No.: 2019krm037).

\begin{abstract}
Based on the national strategy of "new urbanization", from the perspective of urban and rural integration, industrial interaction, economy and intensification, this paper proposes to vigorously promote the industrialization planning of urban and rural housing based on SI system, do a good job in the production of building structural parts from the perspective of building industrialization, extend to the internal filling parts, and do a good job in the internal filling system from the perspective of housing industrialization. At the moment of "Rural Revitalization" strategy, we should first develop the SI system multi-storey industrialized housing to meet the needs of rural areas. At the same time, we put forward the development path of China's urban and rural housing industrialization.
\end{abstract}

Key words: Housing industrialization planning; Building industrialization and new urbanization

Publication date: April, 2021; Publication online: 30 April, 2021

*Corresponding author: Cheng Liu, 2279573107@qq.com

\section{Introduction}

With the coming of state leaders represented by President Xi Jinping and Premier Li Keqiang, China's economic development mode has entered the "new normal". At the same time, China's real estate industry has become the pillar of the national economy. In order to transform it into a quality economic growth mode, the Chinese government has proposed to upgrade the industrial structure, and the development strategy of "new urbanization" should be implemented. The so-called "new urbanization" is characterized by the overall planning of urban and rural areas, the integration of urban and rural areas, industrial interaction, economy and intensive, ecological livable, and harmonious development. It is the coordinated development and mutual promotion of large, small and medium-sized cities, small towns, and new rural communities. The traditional construction production mode, which is almost manual, can not meet the requirements of the new national economic development mode. At the Forum on green construction and sustainable development in 2015, Zhou Fulin, academician of the Chinese Academy of engineering, said that at present, China's construction industrialization level is only $3 \%$ to $5 \%$, while that of European and American countries has reached $75 \%$. Compared with these countries, there is a big gap in the level of construction industrialization in China. On February 22, 2016, the CPC Central Committee and the State Council issued several opinions on Further Strengthening the management of urban planning and construction, which clearly pointed out that China should develop new construction methods, vigorously promote prefabricated buildings, and make prefabricated buildings account for $30 \%$ of new buildings within 10 years. In March 2018, the national development and Reform Commission interpreted the main focus of "new urbanization" after the 19th National Congress of the CPC as follows: Rural revitalization, characteristic town construction and network of large, medium and small cities. Under the background of urbanization development in the 
new historical period, it is imperative to explore the path of urban and rural housing industrialization.

\section{The necessity of top-level design for the development of housing industrialization}

The meaning of housing industrialization is to use the way of industrial production to produce housing, in order to improve the labor productivity of housing production and reduce $\operatorname{costs}^{[1]}$. There is a close relationship between housing industrialization and construction industrialization. Construction industrialization refers to the process of transforming the construction industry from handicraft production to socialized production. Its basic ways are building standardization, factory production of components and fittings, construction mechanization and scientific organization and management, and gradually adopt new achievements of modern science and technology, so as to improve labor productivity, speed up construction, reduce project cost and improve project quality.

\subsection{Status of housing industry in China's construction industry}

The construction industry includes housing industry, factories and buildings, commercial and service housing, office housing, scientific research, education and medical housing, etc. In 2019, according to the composition of the completed area of construction enterprises in China, the completed area of residential buildings accounts for $67.36 \%$; The completed area of factories and buildings accounted for $12.2 \%$; The completed areas of commercial and service buildings and office buildings accounted for 7.11\% and $4.77 \%$ respectively; The completed area of other types of houses accounts for less than 5\% (Figure 1), so the main component of building industrialization is housing industrialization.

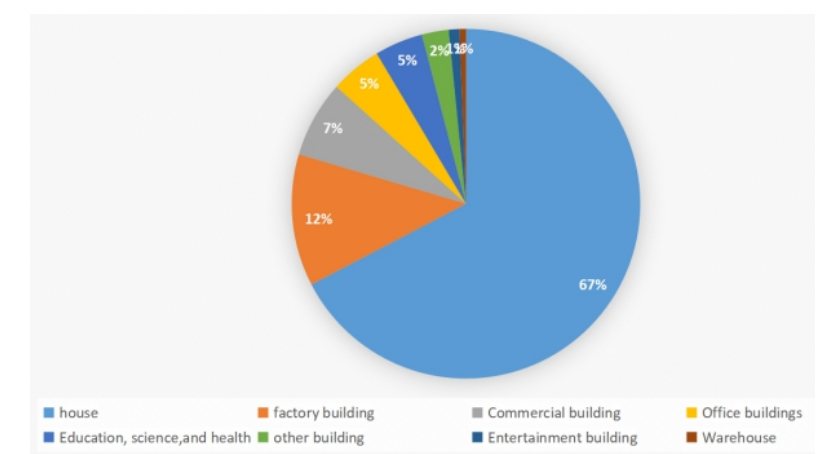

Figure 1. Composition of completed area of buildings of national construction enterprises in 2019

Data source: Statistics and analysis data of Ministry of Housing and Urban-Rural Development

\subsection{The current situation of housing industrialization in China}

At present, the main production mode of China's housing industry is still backward manual production mode. Although it also has the application of modern industrial equipment, it consumes a lot of energy, raw materials and human resources, and the overall production efficiency is not high.

There are also large-scale pilot construction units in China, such as Yuanda housing engineering and Shenzhen Vanke, as shown in Table 1.

Table 1. List of major housing industrialization bases in China

\begin{tabular}{cccc}
\hline $\begin{array}{c}\text { Serial } \\
\text { Number }\end{array}$ & Type & Name & Remarks \\
\hline 1 & Comprehensive & Shenzhen Municipal People's Government \\
2 & urban pilot & Shenyang Municipal People's Government & \\
3 & Government led & Hefei Economic and Technological Development Zone & \\
4 & Development of & Huayuankou Economic Zone, Dalian & \\
5 & housing industry & Seixin Group Building Materials Co., Ltd. & Steel structure \\
7 & Enterprise LED & Qingdao Haier Group & Residential electrical \\
\hline 8 & National base for & Zhejiang Wenzhou Zhengtai Group &
\end{tabular}


Shandong linoret new energy Co., Ltd.

Changsha Yuanda Housing Industry Co., Ltd.

$$
\text { Vanke Enterprise Co., Ltd. }
$$

Nanjing Qixia Construction Co., Ltd.

Zhejiang Shaoxing Baoye Group Co., Ltd.

Heilongjiang Construction Group Co., Ltd.

Shandong Yantai Wanhua Industrial Group Co., Ltd.

Tianjin Housing Construction Development Group Co., Ltd.

Heilongjiang Yuhui Construction Group

Guangzhou Panasonic air conditioning electric appliance Co., Ltd.

Shenzhen Jiada hi tech Industrial Development Co., Ltd. Zhejiang Hangxiao Steel Structure Co., Ltd.

Beijing Jinyu Group Co., Ltd.

Jiangsu Xincheng Real Estate Co., Ltd.

Jiangsu Haimen Zhongnan Holding Group Co., Ltd.

Weifang Guojian Gaochuang Technology Co., Ltd.

Xi'an Jianshe Industrial Co., Ltd.
Solar energy in building integration

Comprehensive demonstration type

Real estate as the core business

Take the development enterprise as the leader

Comprehensive type

Building construction

Polymer products

Production of new building materials

Building construction

Air conditioning products

High tech steel structure

From building materials to comprehensive

Real estate development Comprehensive type Thermal energy saving and high technology Prefabricated concrete structure
2.3 Problems with the development of housing industrialization in China
The development of housing industrialization in China has been explored for more than 20 years, and some progress 
has been made in the field of prefabricated housing, but there are still some shortcomings.

\subsubsection{The pilot enterprises lack of industrial residential product line planning}

The state has carried out the pilot project of building industrialization in the past 20 years, but there is no clear plan for the development of housing industrialization. Therefore, the products of these enterprises are lack of unified planning, and there are phenomena of repeated construction and product features are not prominent. In the pilot project of prefabricated housing, prefabricated concrete structure is the main one. There are few residential projects of steel structure and light steel structure. Compared with the traditional residential construction, it lacks competitive advantage.

\subsubsection{The industry standard is not perfect enough}

Due to the rapid development of China's real estate industry, it seems that we can't wait for the pace of housing industrialization. Therefore, the pilot project of housing industrialization has become an exception rather than the traditional way of building houses. Many pilot enterprises seem to be taking a non-standard road, mainly in the following aspects:

\subsubsection{There is no modular design standard}

The mould of precast concrete structure needs to be made according to the architectural design scheme. If the architectural design scheme also adopts the non modular approach, the production cost of the project mould will be relatively high, which can not reflect the cost advantage of mass production $^{[2]}$.

\subsubsection{Lack of production cost quota standard}

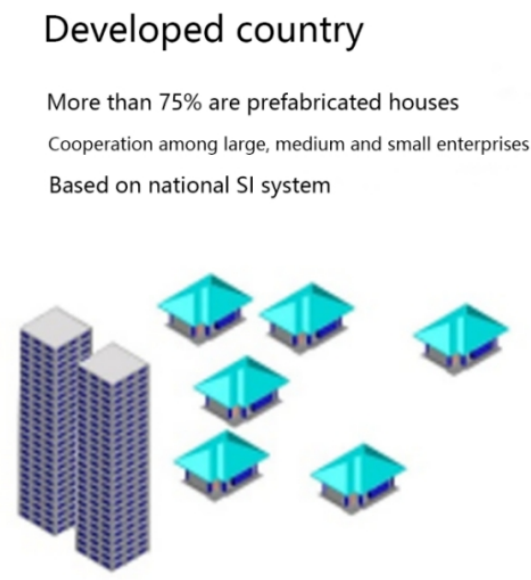

At present, the national engineering cost quota standard of prefabricated structure has not been introduced, and only a few places in the industry, such as Liaoning province, have the quota of prefabricated concrete components, which can not reflect the regional differences. When enterprises participate in bidding, the quotation basis is insufficient.

\subsubsection{The scale cost advantage can not be reflected}

At present, there is a misunderstanding about housing industrialization in China: housing industrialization = prefabricated housing. In this sense, as long as there are a few prefabricated residential factories, the housing industrialization can be realized. As a result, a few prefabricated construction enterprises try to take on the important task of housing industrialization. There is no housing industrialization pattern led by several large enterprises and followed by many small and medium-sized enterprises. Therefore, the lack of industrial scale leads to the price advantage of prefabricated housing, and the market recognition of it is not so high. According to Liu Haoqiang, chief engineer of Xi'an Construction Co., Ltd., which produced the the prefabricated concrete structure residential buildings produced, under the current production capacity, the breakeven point of the enterprise requires the project construction area to reach 300000 square meters. If the project quantity is lower than this value, it will not be profitable. The fundamental reason is that all components of enterprises need to be produced by themselves, the cost can not be reduced, and there is no scale advantage of industrial cluster for division of labor and collaborative production, so the order projects undertaken are very limited, as shown in Figure 2, which illustrates the misunderstanding of China's housing industrialization development.

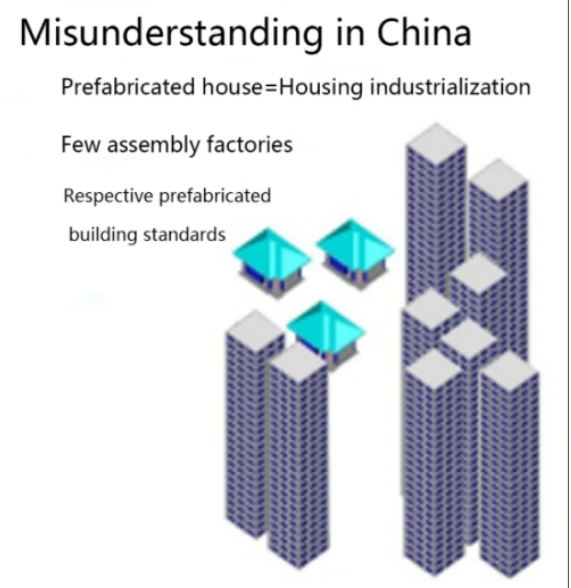

Figure 2. The misunderstanding of housing industrialization in China 


\section{Analysis on the development of housing industrialization under the new urbanization}

The housing industrialization promotion center of the Ministry of Housing and Urban-Rural Development has undertaken the project of housing industrialization planning during the 12th Five Year Plan period. The housing industry should be based on the domestic market. In the future, it will mainly promote prefabricated housing in the field of affordable housing, and has also established 20 major pilot $\operatorname{cities}^{[3]}$. However, under the national strategy of "new urbanization", this orientation needs to be reexamined.

\subsection{Top level design of housing industrialization development}

Throughout the top-level design of housing industrialization in Europe, America, Japan and other developed countries, the so-called prefabricated building system of SI (skeleton and infill) support and filler is implemented. Among them, the support is firm and durable, which solves the service life problem of housing; The filling body can be disassembled to solve the problem of function update. Therefore, the top-level design of housing industrialization in China should first classify the building structure (S) and infill (I) into industrialization. Large construction groups take the route of industrialization of building structure parts, and small and medium-sized home furnishing enterprises take the route of industrialization of internal filling parts. Their integration point lies in the establishment and promotion of national SI standard system. As shown in Figure 3, a house is decomposed according to the idea of SI system. The SI structure system here is not a simple split of traditional brick concrete structure or concrete frame structure. It should be under the new modular SI system standard formulated by the state, the structure (S) and filler (I) can be separated to form their own parts under the two systems. Many small and medium-sized manufacturers can carry out standardized production for the same type of parts of each type of system, and the same type of parts of different manufacturers can be exchanged.

\subsection{The breakthrough point of housing industrialization -- multi storey SI system housing}

According to the number of floors, the residence can be roughly divided into multi-storey residence and high-rise residence. Because of the low floor and relatively small load, the difficulty of design and construction of multi-storey residence is low, while that of high-rise building is on the contrary. At present, many rural villagers self built multi-storey brick concrete structure houses.
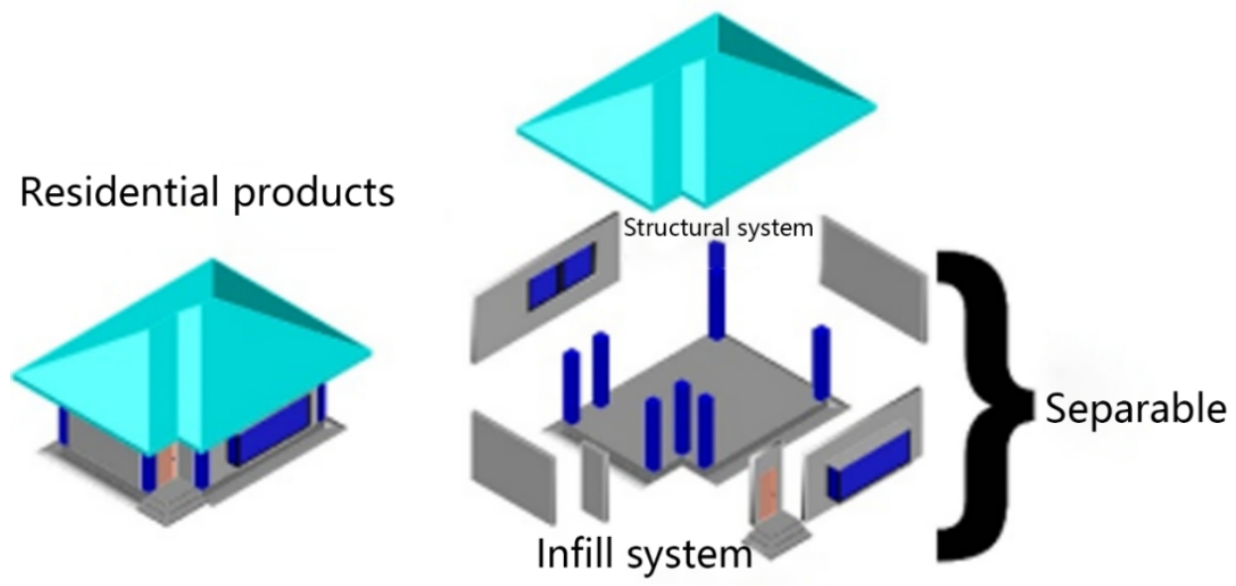

Figure 3. Schematic diagram of SI building system

The house doesn't even have drawings, which shows this. Therefore, the industrialization of housing based on SI system is implemented from multi-storey building, which is easier to realize industrialization production.
Due to historical reasons, the types of building structures in China are influenced by the former Soviet Union. In the field of housing, the main relationship between floors and building structures is shown in Table $2^{[5]}$.

\subsubsection{The relationship between the number of residential}


Table 2. Traditional residential structure and floor relationship in China

\section{Residence}

Arrangement

Brick mixed structure

type

characteristic

Manual production, moderate

cost, environmental pollution
7 / F 24 / F

Above 24 Floors
Concrete shear wall

structure
Concrete shear wall structure

$\begin{array}{cc}\text { Concrete frame structure } & \text { Concrete frame structure } \\ \text { Manual production, soil } & \text { Manual production, high } \\ \text { consumption, low cost, no } & \text { cost, no energy saving } \\ \text { energy saving and } & \text { and environmental } \\ \text { environmental protection } & \text { protection }\end{array}$

Manual production, moderate cost, environmental pollution
Concrete steel mixed structure

Manual production

The cost is high

No energy saving and environmental protection

Manual production

No energy saving and environmental protection
The cost is high

With China's reform and opening up and the pilot development of housing industrialization, the relationship

between prefabricated residential floor and building structure is shown in Table 3.

Table 3. Structure and floor relationship of prefabricated house

\begin{tabular}{|c|c|c|c|}
\hline $\begin{array}{c}\text { Residence } \\
\text { Arrangement }\end{array}$ & Below 7th floor & 7 / F 24 / F & Above 24 floors \\
\hline \multirow{3}{*}{$\begin{array}{l}\text { Structure } \\
\text { type }\end{array}$} & $\begin{array}{c}\text { Prefabricated timber } \\
\text { structure }\end{array}$ & $\begin{array}{c}\text { Fabricated steel } \\
\text { structure }\end{array}$ & Fabricated steel structure \\
\hline & $\begin{array}{c}\text { Prefabricated } \\
\text { Light steel structure }\end{array}$ & $\begin{array}{l}\text { Prefabricated type } \\
\text { Concrete structure } \\
\text { (PC) }\end{array}$ & $\begin{array}{c}\text { Prefabricated type } \\
\text { Concrete structure (PC) }\end{array}$ \\
\hline & $\begin{array}{c}\text { Prefabricated concrete } \\
\text { structure (PC) }\end{array}$ & & \multirow[b]{3}{*}{$\begin{array}{c}\text { Environmental protection } \\
\text { High cost }\end{array}$} \\
\hline \multirow{3}{*}{$\begin{array}{c}\text { Main } \\
\text { characteristic }\end{array}$} & $\begin{array}{c}\text { Environmental } \\
\text { protection and wood } \\
\text { consumption } \\
\text { High cost }\end{array}$ & $\begin{array}{c}\text { Environmental } \\
\text { protection } \\
\text { High cost }\end{array}$ & \\
\hline & $\begin{array}{l}\text { Environmental } \\
\text { protection } \\
\text { High cost }\end{array}$ & $\begin{array}{l}\text { Environmental } \\
\text { protection } \\
\text { High cost }\end{array}$ & \\
\hline & $\begin{array}{l}\text { Environmental } \\
\text { protection } \\
\text { High cost }\end{array}$ & & \\
\hline
\end{tabular}


It can be seen that the traditional residential structure has the advantage of lower cost compared with the prefabricated housing, but its main disadvantages are large resource consumption, low production efficiency and environmental protection. The prefabricated housing mainly has higher cost, but high production efficiency, energy saving and environmental protection. One of the fundamental reasons for the high cost of prefabricated houses is that there is no real industrialization and a small number of production enterprises, mainly because some medium-sized pilot enterprises are doing all-round production of prefabricated houses, and many small and medium-sized enterprise clusters with division of labor are not formed. If such a prefabricated residential enterprise is compared to an automobile manufacturing enterprise, even the headlamp, tire, engine, gearbox and other parts are all produced by itself, then the price of the whole vehicle can not be reduced ${ }^{[6]}$.

\subsubsection{The necessity of developing multi-storey residential industrialization based on SI System}

In recent years, the completed area of urban and rural housing in China is shown in Table 4. According to Table 4, rural housing demand accounts for nearly $40 \%$ of the total social housing demand.

Table 4. Completed area of urban and rural housing in 2012-2016 (10000 square meters)

\begin{tabular}{cccccc}
\hline Particular year & $\mathbf{2 0 1 6}$ & $\mathbf{2 0 1 5}$ & $\mathbf{2 0 1 4}$ & $\mathbf{2 0 1 3}$ & $\mathbf{2 0 1 2}$ \\
\hline $\begin{array}{c}\text { Countryside } \\
\text { peasant household } \\
\text { Whole } \\
\text { Sociology }\end{array}$ & 73051.42 & 79380.2 & 83769.59 & 85952.98 & 87775.93 \\
& 171471.3 & 179737.8 & 192545.1 & 193328.5 & 195102.9 \\
\hline
\end{tabular}

Data source: National Bureau of Statistics (2017 Statistical Yearbook

Because the rural land is not so scarce compared with the city, the majority of rural houses are houses with less than 7 floors, which determines that the implementation of housing industrialization based on SI System in China should mainly consider the low rise prefabricated housing structure type, and from the economic point of view, the prefabricated light steel structure residence based on SI system should be mainly developed (Figure 4).
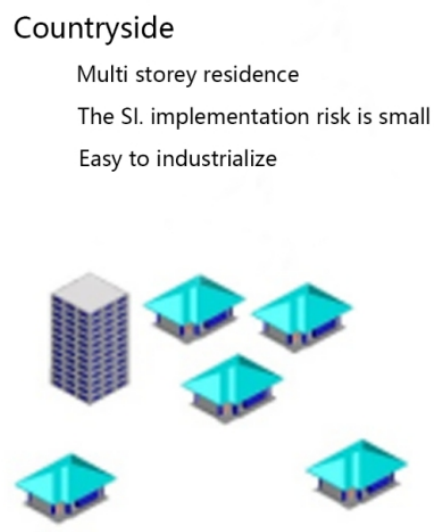

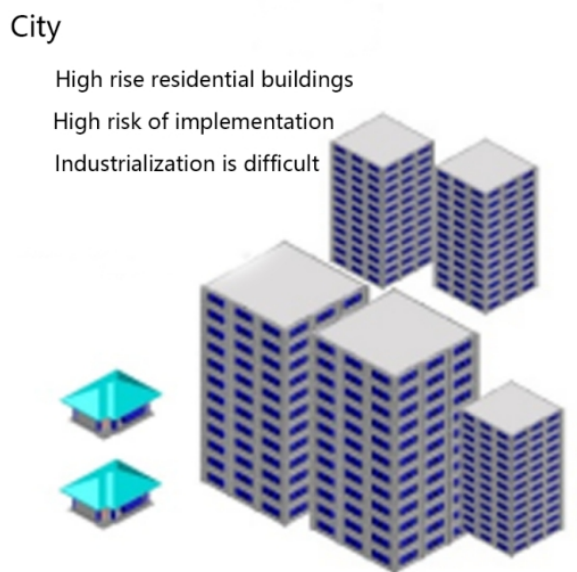

Figure 4. Schematic diagram of the difficulty of implementing SI building system in urban and rural areas

Due to the shortage of urban land, the city mainly considers the high-rise prefabricated buildings with more than 7 floors, and should mainly develop the high-rise prefabricated concrete prefabricated residence and prefabricated steel structure residence based on SI system ${ }^{[7]}$.

\subsection{Cost perspective of housing industrialization development}


In the "new urbanization" development mode, "rural revitalization" has become the focus of development after the 19th National Congress of the CPC. Therefore, the development of housing industrialization should first consider the low floor prefabricated houses. At the same time, in order to obtain the recognition of the demand side of the housing market, prefabricated housing needs to have advantages over the existing building structure types in terms of cost and cost.

\subsubsection{National SI system housing standard and industrialized housing cost}

According to the experience of housing industrialization in Japan, in order to reduce the construction cost of industrial housing and prolong the service life of housing, at the beginning of the top-level design of housing industrialization, the so-called SI system prefabricated building standard is implemented; Among them, the support body is strong and durable, which can solve the service life problem of the residence (up to 100-200 years); The filler can be disassembled to solve the problem of function update (30 years).

In 2006, China began to introduce SI residential structure system, which is restricted by the traditional architectural design and production mode. In addition, the real estate industry is eager to speed up the project, so the promotion effect is not ideal. Under the development mode of "new urbanization" and "rural revitalization", it is necessary to reexamine the advantages of SI building structure system, and timely introduce the SI standard system of multi-storey housing for the implementation of small and medium-sized production enterprises ${ }^{[8]}$.

From the perspective of the implementation standards of prefabricated building pilot enterprises, there are American standards, European standards and Japanese standards. If the standards are not unified and all parts of the enterprise are produced by themselves, the construction cost of such prefabricated houses will be high, and the market price will have no advantage. Therefore, it is necessary to introduce the SI standard system of multi-storey residence in China.

\subsubsection{It is difficult to implement SI structure system in multi-storey residential buildings}

With the idea of SI structure system, the standardization of prefabricated housing is easy to implement. Compared with high-rise buildings, multi-storey residential buildings with less than seven floors are easier to implement, combined with the "new urbanization" development strategy of "rural revitalization, characteristic town construction and large and medium-sized city network". First of all, the standardization of SI construction should be carried out in the multi-storey residential buildings of low rise building type. From the perspective of structural type, the development of steel structure based support and wall system that many manufacturers can participate in is the direction of housing industrialization development in China.

\subsubsection{Foreign SI system multi-storey residential industrialization development is mature}

Japan and some European and American countries already have mature production system and industrial chain of industrialized multi-storey residential parts based on SI system. Because the government has formulated a relatively strict SI standardization system, the SI parts of different enterprises can be exchanged. At the same time, because a large number of enterprises participate in the production of the same type of parts, the advantages of residential industrialization become obvious, and the residential construction cost is greatly reduced, making its production and sales form a virtuous circle. For example, in these countries, the purchase of multi-storey houses is as convenient as furniture, with a wide range of products and many choices for residents. Even the owners can do it yourself. There is a virtuous circle interaction between housing demand and housing supply. Housing industry has really become a stable pillar industry of national economic development ${ }^{[9]}$.

\section{The development path of housing industrialization under the strategy of "Rural Revitalization"}

After the 19th National Congress of the Communist Party of China:"New urbanization" mainly focuses on "rural revitalization, characteristic town construction and network of large, medium and small cities". As an old saying goes, "live in peace and work happily", for the strategy of "rural revitalization", in order to achieve the revitalization of rural characteristic agricultural industry, we must first have a good living environment to attract people who develop rural characteristic industries ${ }^{[10]}$. In the new historical period, to realize the dream of ecological and livable "beautiful countryside", we need to realize the development of urban and rural housing industrialization from the following steps. 
4.1 The standard department should formulate SI national standard for multi-storey residential buildings as soon as possible

Throughout the technology source and standard system adopted by the pilot enterprises of housing industrialization, different enterprises have different technical background and standards. Due to the different technologies and standards among enterprises, it is impossible to form a residential industrialization pattern with interchangeable parts. This is also one of the reasons why housing industrialization is simply equivalent to prefabricated housing in China. Therefore, it is necessary to introduce the design standard of housing industrialization in China based on SI system as soon as possible. This standard should start with multi-storey residential buildings which are relatively easy to realize, and be jointly formulated by the Ministry of Housing and Urban-Rural Development, the Standardization Administration and China Architecture Design \& Research Group.

4.1.1 Type and modulus of domestic industrialized residential structure (s)

\subsubsection{Residential steel structure (s) system}

The steel frame system has the advantages of small section, high strength, easy processing and easy installation. Therefore, the steel frame system should be the first choice in the selection of residential structure. For the standardization of the connection between structural components, considering the detachability of prefabricated housing, the connection forms should be bolt connection, hanging connection, plug-in and other forms, unless the above connection methods are not available and the welding method is adopted ${ }^{[11]}$.

\subsubsection{Residential concrete structure (s) system}

The residential concrete structure (s) system is a mould casting concrete structure component, which has the advantages of low cost and easy modularization, but the disadvantage is that the section size of the component is larger than that of the steel structure. Residential concrete structural members also need to consider their own structural system (s) and the split connection mode with the internal filling system (I).

4.1.2 Type and module of domestic industrial residential interior (I)
The interior decoration of industrialized residence (I) is mainly composed of interior and exterior walls, door and window system, integral kitchen and bathroom, equipment and pipeline system.

\subsubsection{Interior and exterior wall system of multi story residence}

The internal and external wall system is mainly connected with the structure by standardized connection mode. In addition, the external wall should consider the integration of external wall facing layer, insulation layer and interior facing layer, as well as the connection with windows; The interior wall mainly considers the integration with the facing layer and the connection of the door.

\subsubsection{Integrated kitchen and bathroom system}

The kitchen and toilet should be the integrated kitchen and toilet unit, and then the integration and connection of water supply and drainage, heating and ventilation, strong and weak power pipeline system should be considered.

\subsubsection{Equipment pipeline system}

From the perspective of specialty division, the equipment pipeline system should include water supply and drainage, heating and ventilation, strong and weak power pipeline system, and the pipeline system space should be centralized to facilitate maintenance.

\subsection{Upgrading of traditional residential Enterprises}

After the introduction of the national standard based on SI system, the traditional housing industry related enterprises can upgrade the housing industrialization production according to their own technology and advantages.

\subsubsection{Large steel structure construction enterprises}

Large scale steel structure manufacturing enterprises have the advantages of advanced equipment, strong technical force and abundant funds. After the introduction of the national SI system steel structure housing standard, they should do a good job in product research and development. They should be the main suppliers of the steel structure (s) part of multi-storey residential buildings ${ }^{[12]}$.

\subsubsection{Large concrete structure construction enterprises}

These enterprises are mainly composed of prefabricated concrete production enterprises, large-scale concrete component factories and commercial concrete companies, which can produce multi-storey residential concrete structure products based on SI system. 


\subsubsection{Small and medium-sized building wall material manufacturers}

In the past, such enterprises only produced a single wall material. Under the demand of finished filling parts, they need to reorganize and jointly develop and produce filling parts that meet Si national standards.

\subsubsection{Enterprises of kitchen and bathroom related products}

In the past, such enterprises also produced single or multiple products in the field of kitchen and bathroom equipment, which may not be able to produce highly integrated kitchens and toilets. Therefore, they also need to jointly restructure and develop integrated kitchens and toilets in line with $\mathrm{Si}$ standard system ${ }^{[13]}$.

\subsection{The role of the government in the upgrading of traditional residential enterprises}

In the whole process of upgrading traditional residential enterprises, the government should mainly do a good job in supervision and service.

\subsubsection{Government supervision in the upgrading process of traditional housing related enterprises}

(1) Formulate policies and decrees for enterprise upgrading and transformation

From the perspective of sustainable development, we should resolutely shut down the old polluting enterprises related to residential production, limit the backward production capacity enterprises, and encourage the creation and restructuring of new residential enterprises.

(2) Carry out regulatory responsibilities in strict accordance with policies and decrees

As the external driving force of enterprise transformation and upgrading, strict management of enterprise upgrading and transformation in accordance with the law is conducive to the healthy and orderly development of the housing industry towards the direction of new housing industrialization.

4.3.2 Do a good job in the information service of traditional housing industrialization upgrading

In the process of upgrading the traditional housing industry related enterprises, the government should also do a good job in the relevant information services, information platform construction, and guide enterprises to the government's established direction of transformation, reorganization and merger. Under the policy guidance of "rural revitalization, characteristic towns, large and medium-sized cities networking", the goal of housing industrialization in China will be realized (as shown in Figure 5, it shows the development path of housing industrialization based on Si System in China). 


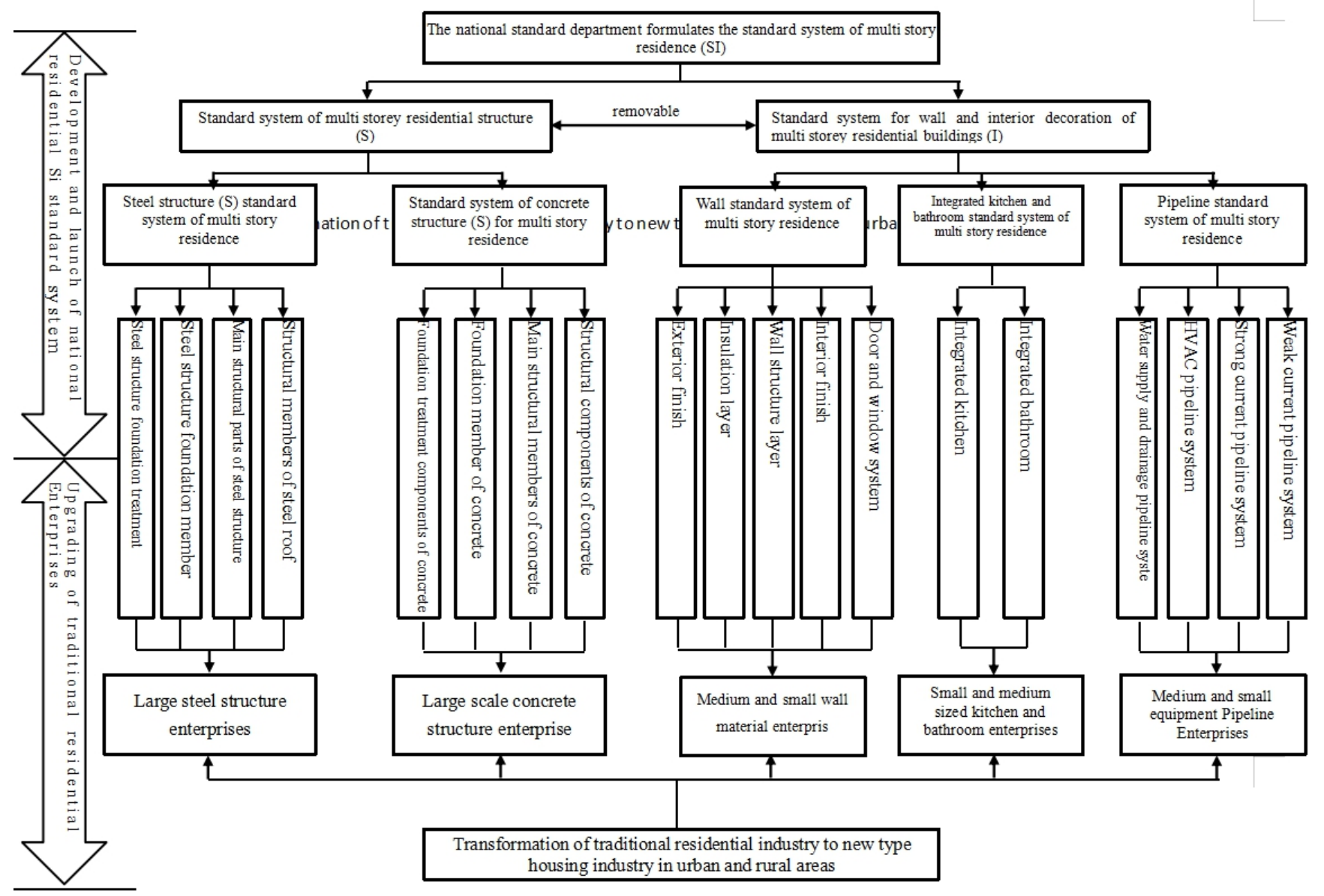

Figure 5. Development of urban and rural housing industrialization based on SI system

\section{Conclusion}

In the current situation of China's economic development, industrial structure adjustment and industrial upgrading are imperative. "Rural revitalization, characteristic town construction and network of large, medium and small cities" under "new urbanization" is China's national development strategy in the new historical period ${ }^{[14]}$. If we want to achieve the social goals of urban and rural overall planning, urban and rural integration, industrial interaction, conservation and intensive, ecological livable and harmonious development. With the accumulation of nearly 20 years of residential industrialization pilot experience, the development of multi-storey residential industrialization based on SI national standard system should be taken as the breakthrough point. Large construction groups should start from the industrial residential structure (S) part and expand to the internal filling (I) part. Small and medium-sized home furnishing enterprises should make the filling (I) part well. As far as possible to the multi-storey residential structure system (S) part of the extension, truly achieve a few residential. The housing industrialization development pattern is dominated by large enterprises in the production of industrial parts and participated by many small and medium-sized enterprises in the production of industrial parts of housing. The core of all this is to do a good job in the top-level development planning of housing industrialization.

\section{References}

[1] Li ZF. Further discussion on housing industrialization and construction industrialization $[\mathrm{J}]$. Construction Economy, 2018,39 (01): 5-10.

[2] Liu YS. Research on modular pricing model of residential engineering based on BIM [J]. Construction Economy, 2013, 9 (237): 198-101. Shan YH. Research on the integration mechanism of housing industry chain oriented to construction industrialization [D]. Harbin: Harbin Institute of Technology, 2014.12:1.

[3] Wang SS. Research on promoting the development of new building industrialization under the background 
ofurbanization [D]Shandong Jianzhu University, April 2014:27.

[4] Shen W. Housing industrialization research and development strategy analysis [D]. Chongqing: Chongqing Jiaotong University:23.

[5] Liu J. Research on the reasonable choice of urban residential height in China [D]. Chongqing University, 2015

[6] Liu $\mathrm{H}$. The impact of new urbanization strategy on the spatial pattern of China's land development [J]. Progress in Geographical Science, 2015, 34 (5): 1545-553.

[7] Liu Y, Li ZF. Research on SI architecture development based on industrial system integration $[\mathrm{J}]$. Construction Economy, 2015,36 (07): 5-8.

[8] Zhang BT. Modular design method of housing industrialization based on BIM [J]. Intelligent City, 2017,3 (12): 35-36.
[9] Qi BK, Zhang Y. Bottleneck and countermeasures of prefabricated building development [J]. Journal of Shenyang Jianzhu University (Social Science Edition), 2015,17 (02): 156-159.

[10] Cui XM. Dynamic factors of urban housing price and its empirical research [D]. Zhejiang University, 2003

[11] Jia L. Regional comparative study on the development potential of housing industrialization in China [D] Chongqing University, 2015.

[12] Gao S. Research on promoting the stable and healthy development of commercial housing market in Western China [D]. Guangxi University, 2012

[13] Gong SR. Research on policy system of rural housing industrialization [D]. Northwest A \& F University, 2009

[14] Liu DW, Jiang HB, Yu L. Development of China's housing industrialization and its technological evolution [J]. Acta Architecturae Sinica, 2012 (4): 10-18. 